\title{
Stage II Rectosigmoid Cancer AJCC v6
}

National Cancer Institute

\section{Source}

National Cancer Institute. Stage I/ Rectosigmoid Cancer A/CC v6. NCI Thesaurus. Code C5015.

Stage II includes IIA (T3, NO, MO) and IIB (T4, N0, M0). T3: T umor invades through the muscularis propria into the subserosa, or into nonperitonealized pericolic or perirectal tissues. T4: Tumor directly invades other organs or structures, and/or perforates the visceral peritoneum. N0: No regional lymph node metastasis. M0: No distant metastasis. (AJCC 6th ed.) 